University of Nebraska - Lincoln

DigitalCommons@University of Nebraska - Lincoln

Agronomy \& Horticulture -- Faculty Publications

Agronomy and Horticulture Department

2006

Soil Organic Carbon Changes in Diversified Rotations of the Western Corn Belt

\author{
Gary E. Varvel \\ University of Nebraska-Lincoln, gevarvel@windstream.net
}

Follow this and additional works at: https://digitalcommons.unl.edu/agronomyfacpub

Part of the Plant Sciences Commons

Varvel, Gary E., "Soil Organic Carbon Changes in Diversified Rotations of the Western Corn Belt" (2006). Agronomy \& Horticulture -- Faculty Publications. 329.

https://digitalcommons.unl.edu/agronomyfacpub/329

This Article is brought to you for free and open access by the Agronomy and Horticulture Department at DigitalCommons@University of Nebraska - Lincoln. It has been accepted for inclusion in Agronomy \& Horticulture -Faculty Publications by an authorized administrator of DigitalCommons@University of Nebraska - Lincoln. 


\section{Soil Organic Carbon Changes in Diversified Rotations of the Western Corn Belt}

\begin{abstract}
Sequestration and storage of carbon (C) by agricultural soils has been cited as one potential part of the solution to soil degradation and global climate change. However, $C$ sequestration in soils is a slow and dynamic process. The objective of this study was to evaluate the effects of crop rotation and $\mathbf{N}$ fertilizer management on soil organic $\mathbf{C}$ (SOC) levels at several points in time during $18 \mathrm{yr}$ of a long-term study in the Western Corn Belt. Seven cropping systems (three monoculture, two 2-yr, and two 4-yr rotations) with three levels of $\mathbf{N}$ fertilizer were compared. Soil samples were taken in the spring in 1984, 1992, 1998, and 2002 to a depth of $30 \mathrm{~cm}$ in 0- to 7.5-, 7.5- to 15-, and 15- to 30-cm increments. No differences were obtained in SOC levels in 1984 at the beginning of the study. After 8 yr, rotation significantly increased SOC $449 \mathrm{~kg} \mathrm{ha}^{-1}$ across all cropping systems. From 1992 to 2002, SOC levels in the 0- to $7.5-\mathrm{cm}$ depth decreased by $516 \mathrm{~kg} \mathrm{ha}^{-1}$ across all cropping systems. Soil organic $C$ levels in the $7.5-$ to $15-\mathrm{cm}$ depths in 1992 and 2002 demonstrated similar rotation effects to those in the surface 0 - to $7.5-\mathrm{cm}$, being not significantly affected from 1984 to 1992 but being significantly decreased from 1992 to $2002\left(568 \mathrm{~kg} \mathrm{SOC} \mathrm{ha}^{-1}\right.$ across all cropping systems). Many of the SOC gains in the surface $30 \mathrm{~cm}$ measured during the first $8 \mathrm{yr}$ of the study were lost during the next $10 \mathrm{yr}$ in all but the 4-yr cropping systems after $18 \mathrm{yr}$. The loss of SOC in this latter period occurred when depth of tillage was increased by using a tandem disk with larger-diameter disks. These results demonstrate that more than one point-in-time measurement from long-term experiments is necessary to monitor SOC changes when several management variables, such as cropping system and $\mathrm{N}$ fertilizer, are being used. They also indicate that apparent small changes in cultural practices, such as in depth of tillage in this experiment, can significantly change SOC dynamics in the soil. Subtle changes in cultural practices (e.g., tillage depth) can have significant long-term results, but longterm experiments are required to quantify their impact under variable climatic conditions.
\end{abstract}

$I_{\mathrm{f}}^{\mathrm{N}}$ NTEREST in $\mathrm{C}$ sequestration in soils and its potential for reducing emissions of greenhouse gasses has increased greatly in the last 10 to $15 \mathrm{yr}$. This interest is evidenced by the large number of studies into this topic. Jarecki and Lal (2003), through the review of 220 references, point out the need for adoption of what they call "recommended management practices" that will help fill the large C sink in the world's agricultural soils. Such management strategies include crop rotations and tillage practices, cover crops, ley farming, agroforestry, use of organic waste materials, $\mathrm{N}$ fertilization, precision farming, and irrigation.

West and Post (2002) presented a global analysis of SOC sequestration rates as affected by tillage and crop

G.E. Varvel, USDA-ARS and Dep. of Agronomy and Horticulture, Univ. of Nebraska, Lincoln, NE 68583. Joint contribution of USDAARS and the Nebr. Agric. Res. Div., Journal Series No. 14997. Received 31 Mar. 2005. *Corresponding author (gvarvel1@unl.edu).

Published in Soil Sci. Soc. Am. J. 70:426-433 (2006).

Soil \& Water Management \& Conservation

doi:10.2136/sssaj2005.0100

(c) Soil Science Society of America

677 S. Segoe Rd., Madison, WI 53711 USA rotation from 67 long-term agricultural experiments from around the world. They indicated that increased $\mathrm{C}$ sequestration is obtained by decreasing soil disturbance, such as changing from conventional to no-tillage systems, or by enhancing rotation complexity. Enhancing of rotation complexity is defined as (i) a change from monoculture to continuous rotation cropping, (ii) a change from crop-fallow systems to continuous monoculture or rotation cropping, and (iii) an increase in the number of crops used in a rotation cropping system. They noted that soil $\mathrm{C}$ sequestration rates in response to either of these types of management practice changes can have a delayed response, reaching peak sequestration rates between 5 and $10 \mathrm{yr}$ after initiation and then declining to near zero after 15 to $20 \mathrm{yr}$. Similar conclusions have been reported in a review by Lal et al. (1998) based on results from Franzluebbers and Arshad (1996). It is important to examine these practices in long-term studies because of the amount of time required for many of these management practices to significantly change SOC content.

Recently, several researchers have presented results from studies after 23 to $48 \mathrm{yr}$ of different management scenarios. Allmaras et al. (2004) and Wilts et al. (2004) present information from a 29-yr study in Minnesota on the effects of harvest management on corn residue transformations and belowground materials into soil C. They reported that the aboveground stover contribution to SOC was greatest in the moldboard plow (MB) system followed by the chisel plow $(\mathrm{CH})$ system and no-till (NT) systems, whereas below-ground (roots, crowns, exudates) contributions to SOC were greatest in NT systems followed by $\mathrm{CH}$ systems $\mathrm{MB}$ systems. Although these changes were sometimes small, the authors noted that these differences were obtained with small but subtle changes in management practices. Similarly, Booker et al. (2005) reported similar results on the long-term effects of tillage and corn stalk return on soil C dynamics from a study conducted for $28 \mathrm{yr}$ in Connecticut. In Iowa, Russell et al. (2005) reported results taken from two studies 23 and $48 \mathrm{yr}$ old on the effects of $\mathrm{N}$ fertilization and cropping system on $\mathrm{C}$ sequestration. In each of these reports, the importance of data from long-term studies becomes evident by quantifying the impact that small changes in management practices have with time. These reports present current SOC conditions after 23 to $48 \mathrm{yr}$ of different management practices, but they provide little if any information on soil $\mathrm{C}$ dynamics throughout the duration of the studies.

Most of the previous reports present measurements from one or two points in time, usually at the beginning and end of the study period. Many of them report differences in organic matter or some form of SOC at the current point in time because few, if any, of the studies were extensively sampled at their initiation. This 
approach permits the determination of type and magnitude of SOC change averaged for the time period but provides little process information that may govern SOC during the period. This can be especially important in long-term studies that may have undergone several different management changes over the years of the study. These changes in management may have had some relatively short-term affects on organic matter or SOC, but without measurements in the interim periods of the study, these changes may not be detected. Opportunities to make these kinds of measurements in long-term studies are limited because few of these studies are sampled at their initiation and throughout their duration. Given the lack of this type of information, the objective of this study was to evaluate the effect of crop rotation and $\mathrm{N}$ fertilizer management on SOC levels at several points in time during $18 \mathrm{yr}$ in a long-term study in the Western Corn Belt.

\section{MATERIALS AND METHODS}

The experiment was conducted on the Agronomy Farm at the University of Nebraska Agricultural Research and Development Center near Mead, Nebraska on a Sharpsburg silty clay loam (fine, smectitic, mesic Typic Argiudoll). Seven cropping systems (three monoculture, two 2-yr rotations, and two 4-yr rotations) with three rates of $\mathrm{N}$ fertilizer were evaluated in the study beginning in 1982. Monocultures included continuous corn [Zea mays L.], soybean [Glycine $\max ($ L.) Merr.], and grain sorghum [Sorghum bicolor (L.) Moench]. The 2-yr rotations were corn/soybean and grain sorghum/soybean, and the two 4-yr rotations were oat [Avena sativa (L.)] + clover [ $80 \%$ Melilotus officinalis (L.) and 20\% Trifolium pratense/grain sorghum/soybean/corn and soybean/ grain sorghum/oat +clover/corn. Each crop phase of every rotation was present every year for a total of 15 rotation treatments per block. Treatments were assigned to experimental units ( 9 by $32 \mathrm{~m}$ ) in factorial combinations of rotation and crop within rotation in four blocks. A fifth randomized complete block including all of the treatments was initiated in 1983, but data were not used from it until after the 1986 season, when all rotations in that block had completed one cycle. The fifth block was added because land became available and because an additional replication was desirable for longterm analyses.

No fertilizer $\mathrm{N}$ was applied to any of the monoculture or rotation plots during the first cropping season. Three subplots ( 9 by $10 \mathrm{~m}$ ), separated by $1 \mathrm{~m}$ alleys, were randomly assigned a 0 , low, or high $\mathrm{N}$ rate within each whole plot treatment starting with the 1983 cropping season. Nitrogen rates were 0,90 , or $180 \mathrm{~kg} \mathrm{ha}^{-1}$ for corn and grain sorghum and 0,34 , or $68 \mathrm{~kg} \mathrm{ha}^{-1}$ for soybean and oat + clover crops. Nitrogen was side-dressed as liquid urea-ammonium nitrate solution (32-0-0) in 1983 and 1984 and has been broadcast as granular ammonium nitrate (34-0-0) in succeeding years. Oat+clover plots were fertilized shortly after planting by broadcasting granular ammonium nitrate. Nitrogen was applied in early- to mid-June for corn, grain sorghum, and soybean plots.

Cultural practices were typical of those used by local producers. The previous crop residue from corn or grain sorghum was shredded in late fall, followed by tillage that consisted of disking once or twice $10-15 \mathrm{~cm}$ deep in the spring just before planting from 1983 through 1991. After 1992, a disk with larger diameter disks was used for tillage, resulting in an effective depth of tillage of $15-20 \mathrm{~cm}$ deep.
Oat was seeded as early as possible in the spring in $18 \mathrm{~cm}$ rows at a rate of $100 \mathrm{~kg} \mathrm{seed} \mathrm{ha}^{-1}$. Rhizobium-inoculated clover was seeded at $18 \mathrm{~kg} \mathrm{ha}^{-1}$ in the same operation. A corn hybrid adapted to eastern Nebraska was planted with a six-row planter in 76-cm rows at a rate of 47000 viable seeds $\mathrm{ha}^{-1}$. Soybean and grain sorghum were seeded in 76-cm rows at rates of 370000 and 173000 seeds ha ${ }^{-1}$, respectively. Every 4 yr, hybrid and variety selections were reviewed, and changes to newer hybrids or varieties were made if deemed appropriate. Weed control was accomplished using combinations of crop-specific selective herbicides in pre-emergence applications along with in-season cultivation in corn, soybean, and grain sorghum. Herbicides were selected for each rotation to obtain optimum weed control and to reduce carryover problems for successive crops in that rotation.

Dry-matter samples for oat were collected at physiologic maturity by harvesting three rows $5 \mathrm{~m}$ in length. These samples were dried and weighed for dry-matter yield determinations before being threshed to separate grain and straw using a stationary plot thresher. Aboveground dry-matter samples (1 row by $5 \mathrm{~m}$ ) for corn were collected each year soon after physiologic maturity. Ears were removed, and stalks were cut at ground level, chopped, dried, and weighed for stover drymatter yield determination. The ears were shelled, and grain was weighed to determine grain yields. Dry-matter samples ( 1 row by $5 \mathrm{~m}$ ) were collected each year for soybean and grain sorghum at physiologic maturity. Soybean samples were dried and weighed for dry-matter yield determination before being threshed using a stationary plot thresher to determine grain yields. Heads removed from grain sorghum whole plant samples were dried, weighed, and threshed for grain yields. Grain sorghum whole plants were chopped, dried, and weighed for dry-matter yield determination. The remaining crops in all plots were harvested with commercially available field combines. Straw spreaders on the combines returned all crop residues back to that plot. Additional details and specifics regarding planting and harvest procedures are presented in Peterson and Varvel (1989a, 1989b, 1989c).

Soil samples were taken to establish base soil C levels in the spring of 1984 from only the first four blocks. Fifteen cores (1.8 cm diameter) were taken to a depth of 30-cm in 0- to 7.5-, 7.5- to 15-, and 15- to 30-cm depth increments from each rotation whole plot treatment and composited by depth. Soil samples for this study were also taken in 1992, 1998, and 2002. In these subsequent years, fifteen cores were taken from each $\mathrm{N}$ rate subplot within each rotation whole plot treatment from all five blocks from the same depths.

All samples were air-dried, ground to pass a 2-mm screen, and analyzed for total $\mathrm{C}$ using an automatic $\mathrm{C}$ analyzer, a Carlo Erba Model 1500 CNS Analyzer (Carlo Erba Strumentazione, Milan, Italy) interfaced with a continuous-flow mass spectrometer, and a Tracer Mass Stable Isotope Spectrometer (Europa Scientific Limited, Crewe, England) (Schepers et al., 1989). Total C equated to soil organic C (SOC) because all soils were at a $\mathrm{pH}$ of 6.5 or lower. Soil bulk density was determined for the 1998 and 2002 sampling times by using the volume and dry weights from the 15 sample cores from each subplot.

Soil organic $\mathrm{C}$ values were analyzed separately for each of the years. Whole plot (rotation) samples were taken in 1984 before subplots ( $\mathrm{N}$ fertilizer levels) were established, so SOC values were calculated on a whole-plot basis using the average bulk density values from all three $\mathrm{N}$ fertilizer level subplots. In 1992, 1998, and 2002 when all subplots were sampled, SOC values were calculated for each rotation and $\mathrm{N}$ fertilizer level combination. Orthogonal comparisons were used to partition rotation sums of squares (Steel and Torrie, 1980). All statistical analyses were performed using the Statistical Analyses System (SAS Institute, 1992). 


\section{RESULTS}

Statistical analyses of the bulk density measurements from 1998 and 2002 sampling dates indicated no significant differences among treatments (rotation and $\mathrm{N}$ rates) (data not shown). Because there were no significant treatment effects and because bulk density measurements from 1984 and 1992 had not been taken from all plots, bulk density values from 1998 and 2002 were averaged for each subplot and depth. Those values were used with total $\mathrm{C}$ concentrations measured in soil samples taken in 1984, 1992, 1998, and 2002 to calculate SOC values for each subplot and depth combination every year. Bulk density values from the $0-$ to $7.5-$ and $7.5-$ to $15-\mathrm{cm}$ depths from 1998 and 2002 averaged 1.16 and $1.38 \mathrm{Mg} \mathrm{m}^{-3}$, respectively, and were similar to those used by Varvel (1994) (1.20 and $1.35 \mathrm{Mg} \mathrm{m}^{-3}$ ) to calculate SOC changes in the surface $15 \mathrm{~cm}$.

Total SOC values calculated for all depths using the above approach for 1984 and 1992 are shown in Table 1. Statistical analyses of these results produced similar conclusions to those reached previously (Varvel, 1994) when only SOC concentrations were analyzed because bulk density values from all plots had not been taken. In that study, it was shown that at the beginning of the study in 1984, no significant differences between rotations in SOC concentrations existed, which is the same result shown in Table 1. Similarly, results from analyses of the 1992 data presented in Table 1 indicate that total SOC values were significantly different between rotations in the surface 0 - to $7.5-\mathrm{cm}$ depth, with most of that difference being attributed to comparisons between the 2-yr $\left(14.70 \mathrm{Mg} \mathrm{ha}^{-1}\right)$ and 4-yr rotations $\left(15.87 \mathrm{Mg} \mathrm{ha}^{-1}\right)$, which were similar to SOC concentrations reported previously by Varvel (1994).

Soil organic $\mathrm{C}$ changes that occurred during the first $8 \mathrm{yr}$ of the study encouraged investigation into possible long-term cropping system effects. Soil organic C values determined from soil samples taken from all five blocks in 1992, 1998, and 2002 are presented in Table 2. Soil organic $\mathrm{C}$ results are also presented again for the 1992 sampling, but these results now include those from the fifth block. These analyses from four blocks (Table 1 ) are similar to those from all five blocks (Table 2) for the 1992 data (i.e., the addition of the fifth block did not change our results). Total SOC values in 1998 and 2002 at all depths were significantly different between rotations (Table 2), which is consistent with results obtained in

Table 1. Total SOC in 1984 for each rotation and 1992 for each rotation and $\mathrm{N}$ level at the 0- to 7.5-, 7.5- to 15-, and 15- to 30-cm depths in the first four blocks at Mead, Nebraska.

\begin{tabular}{|c|c|c|c|c|c|c|c|}
\hline \multirow[b]{3}{*}{ Rotation $\dagger$} & \multirow[b]{3}{*}{ N level } & \multicolumn{6}{|c|}{ Depths (cm) } \\
\hline & & \multicolumn{3}{|c|}{1984} & \multicolumn{3}{|c|}{1992} \\
\hline & & $0-7.5$ & 7.5-15 & 15-30 & $0-7.5$ & 7.5-15 & 15-30 \\
\hline & & \multicolumn{6}{|c|}{ — Total SOC $\left(\mathrm{Mg} \mathrm{ha}^{-1}\right)$} \\
\hline \multirow[t]{3}{*}{$\mathbf{C C}$} & 0 & 15.72 & 15.08 & 23.71 & 14.85 & 15.08 & 21.22 \\
\hline & Low & & & & 15.96 & 15.38 & 21.93 \\
\hline & High & & & & 16.31 & 15.78 & 22.70 \\
\hline \multirow[t]{3}{*}{ CSB } & 0 & 15.10 & 16.14 & 27.70 & 15.04 & 16.13 & 25.94 \\
\hline & Low & & & & 15.00 & 15.73 & 24.64 \\
\hline & High & & & & 14.67 & 15.65 & 24.47 \\
\hline \multirow[t]{3}{*}{ CSG } & 0 & 15.30 & 15.47 & 26.61 & 15.71 & 15.54 & 25.00 \\
\hline & Low & & & & 16.16 & 15.81 & 22.38 \\
\hline & High & & & & 16.71 & 15.58 & 23.68 \\
\hline \multirow[t]{3}{*}{ C/SB } & 0 & 14.44 & 15.48 & 26.07 & 14.42 & 15.19 & 23.78 \\
\hline & Low & & & & 14.75 & 15.45 & 23.60 \\
\hline & High & & & & 14.59 & 15.19 & 23.19 \\
\hline \multirow{3}{*}{ SG/SB } & 0 & 14.39 & 14.85 & 22.49 & 14.64 & 14.97 & 20.10 \\
\hline & Low & & & & 14.60 & 14.67 & 20.16 \\
\hline & High & & & & 15.21 & 15.01 & 20.67 \\
\hline \multirow[t]{3}{*}{ OCL/SG/SB/C } & 0 & 15.46 & 15.89 & 27.07 & 16.09 & 16.07 & 25.82 \\
\hline & Low & & & & 15.98 & 15.82 & 24.37 \\
\hline & High & & & & 16.83 & 16.18 & 25.54 \\
\hline \multirow[t]{3}{*}{ SB/SG/OCL/C } & 0 & 14.37 & 15.33 & 24.90 & 15.24 & 15.29 & 23.86 \\
\hline & Low & & & & 15.33 & 15.14 & 22.51 \\
\hline & High & & & & 15.75 & 15.11 & 23.40 \\
\hline Source of variation & df & \multicolumn{6}{|c|}{ Mean squares } \\
\hline Block & 3 & $10.19 * *$ & $13.72 * * * *$ & $96.90 * *$ & $14.71 * * *$ & $20.62 * *$ & $129.81 * * *$ \\
\hline Rotation & 6 & 1.27 & 0.79 & 14.21 & $5.55 * *$ & 1.88 & 26.25 \\
\hline Cont vs. rotn. & 1 & 3.35 & 0.21 & 5.05 & 2.05 & 1.74 & 11.14 \\
\hline 2 yr vs. 4 yr $\div$ & 1 & 0.99 & 0.78 & 11.42 & $16.36 * *$ & 3.27 & 22.98 \\
\hline Among 2 yrt & 1 & 0.01 & 0.79 & 25.65 & 0.32 & 0.93 & 44.71 \\
\hline Among 4 yr & 1 & 2.45 & 0.64 & 9.29 & 4.41 & 4.24 & 31.99 \\
\hline $\mathbf{N}$ level & 2 & & & & 2.41 & 0.04 & 5.90 \\
\hline Rotation $\times \mathbf{N}$ & 12 & & & & 0.47 & 2.42 & 1.50 \\
\hline Error & (18) $(60) \S$ & 1.49 & 1.44 & 18.97 & 1.49 & 1.60 & 15.40 \\
\hline
\end{tabular}


Table 2. Total SOC in 1992, 1998, and 2002 for each rotation and $\mathrm{N}$ level at the 0- to 7.5-, 7.5- to 15-, and 15- to 30-cm depths in all five blocks at Mead, Nebraska.

\begin{tabular}{|c|c|c|c|c|c|c|c|c|c|c|}
\hline \multirow[b]{3}{*}{ Rotation $\dagger$} & \multirow[b]{3}{*}{$\mathbf{N}$ level } & \multicolumn{9}{|c|}{ Depths (cm) } \\
\hline & & \multicolumn{3}{|c|}{1992} & \multicolumn{3}{|c|}{1998} & \multicolumn{3}{|c|}{2002} \\
\hline & & $0-7.5$ & $7.5-15$ & 15-30 & $0-7.5$ & $7.5-15$ & 15-30 & $0-7.5$ & $7.5-15$ & 15-30 \\
\hline & & & & & - T & tal SOC $(M$ & $\left.\mathbf{a}^{-1}\right)$ & & & \\
\hline \multirow[t]{3}{*}{$\mathbf{C C}$} & $\mathbf{0}$ & 14.67 & 14.69 & 23.37 & 13.48 & 13.94 & 22.20 & 13.05 & 13.40 & 20.64 \\
\hline & Low & 15.51 & 15.01 & 23.28 & 14.84 & 14.43 & 21.73 & 14.36 & 13.91 & 21.23 \\
\hline & High & 15.80 & 15.44 & 23.48 & 15.42 & 15.06 & 22.69 & 15.04 & 14.54 & 22.00 \\
\hline \multirow[t]{3}{*}{ CSB } & 0 & 14.75 & 15.92 & 26.82 & 14.07 & 15.68 & 26.12 & 13.88 & 14.96 & 25.16 \\
\hline & Low & 14.67 & 15.52 & 25.64 & 14.20 & 15.30 & 24.65 & 13.91 & 14.90 & 24.05 \\
\hline & High & 14.73 & 15.45 & 25.82 & 14.07 & 14.93 & 24.88 & 14.32 & 15.10 & 24.34 \\
\hline \multirow[t]{3}{*}{ CSG } & 0 & 15.82 & 15.54 & 25.85 & 15.39 & 15.20 & 25.49 & 15.22 & 15.05 & 24.52 \\
\hline & Low & 16.17 & 15.63 & 25.18 & 15.80 & 15.34 & 23.62 & 15.82 & 15.09 & 22.33 \\
\hline & High & 16.60 & 15.53 & 25.08 & 16.26 & 15.51 & 24.12 & 15.99 & 15.19 & 23.59 \\
\hline \multirow[t]{3}{*}{ C/SB } & 0 & 14.56 & 15.03 & 25.42 & 13.99 & 14.67 & 24.65 & 13.98 & 14.51 & 24.15 \\
\hline & Low & 14.95 & 15.44 & 25.62 & 14.22 & 14.54 & 24.34 & 14.15 & 14.72 & 24.06 \\
\hline & High & 14.72 & 15.38 & 24.75 & 14.30 & 14.72 & 23.91 & 14.45 & 14.76 & 23.87 \\
\hline \multirow[t]{3}{*}{ SG/SB } & 0 & 14.67 & 14.87 & 22.67 & 13.94 & 14.08 & 21.51 & 13.86 & 14.03 & 20.83 \\
\hline & Low & 14.76 & 14.77 & 22.96 & 14.46 & 14.19 & 21.70 & 14.40 & 14.05 & 21.26 \\
\hline & High & 15.03 & 14.78 & 22.64 & 14.50 & 14.11 & 21.50 & 14.46 & 14.18 & 20.84 \\
\hline \multirow[t]{3}{*}{ OCL/SG/SB/C } & 0 & 16.08 & 15.87 & 26.75 & 15.78 & 15.54 & 26.10 & 15.92 & 15.53 & 25.53 \\
\hline & Low & 16.13 & 15.85 & 25.83 & 15.96 & 15.49 & 25.56 & 15.99 & 15.71 & 24.84 \\
\hline & High & 16.64 & 15.89 & 26.97 & 16.51 & 15.67 & 26.49 & 16.60 & 15.66 & 25.54 \\
\hline \multirow{3}{*}{ SB/SG/OCL/C } & 0 & 15.41 & 15.32 & 24.93 & 15.38 & 14.79 & 24.51 & 15.46 & 15.08 & 24.33 \\
\hline & Low & 15.59 & 15.30 & 24.69 & 15.18 & 14.55 & 24.30 & 15.48 & 14.85 & 23.41 \\
\hline & High & 16.02 & 15.24 & 24.82 & 15.63 & 14.99 & 24.33 & 16.14 & 15.32 & 24.04 \\
\hline Source of variation & $\underline{\text { df }}$ & \multicolumn{9}{|c|}{ Mean squares } \\
\hline Block & 4 & 11.11** & $16.68 * * *$ & $97.92 * * *$ & 6.35*** & $18.53 * * *$ & $110.19 * * *$ & $8.57 * * *$ & $22.98 * * *$ & 101.92*** \\
\hline Rotation & 6 & 6.81*** & 1.97 & $28.28 *$ & $10.24 * * *$ & 4.16* & 38.05* & $12.74 * * *$ & $\mathbf{5 . 3 8} * * *$ & $39.60 * *$ \\
\hline Cont. vs. rotn. & 1 & 0.03 & 0.27 & 0.31 & 0.58 & 1.81 & 0.44 & $5.31 *$ & 0.87 & 5.48 \\
\hline 2 yr vs. 4 yr & 1 & $21.45 * * *$ & 4.22 & 41.27 & 34.02 $* * *$ & $9.29 * *$ & 78.04*** & $44.15 * * *$ & $14.51 * * *$ & $66.90 *$ \\
\hline Among 2 yr $\nleftarrow$ & 1 & 0.05 & 1.69 & 47.05 & 0.12 & 1.97 & 56.04 & 0.02 & 2.50 & $69.75^{*}$ \\
\hline Among 4 yrit & 1 & 2.82 & 2.57 & 21.72 & 3.48 & 4.66 & 20.90 & 1.74 & 0.99 & 14.13 \\
\hline N level $\neq$ & 2 & 2.29 & 0.04 & 1.42 & 3.87* & 0.30 & 3.91 & $5.67 * *$ & 0.92 & 3.08 \\
\hline Rotation $\times \mathbf{N}$ & 12 & 0.26 & 0.21 & 0.77 & 0.60 & 0.41 & 1.16 & 0.48 & 0.21 & 1.55 \\
\hline Error & 80 & 1.38 & 1.35 & 12.90 & 0.99 & 1.48 & 15.06 & 0.89 & 1.16 & 13.01 \\
\hline
\end{tabular}

$\dagger \mathrm{CC}=$ continuous corn; $\mathrm{CSB}=$ continuous soybean; $\mathrm{CSG}=$ continuous grain sorghum; $\mathrm{C} / \mathrm{SB}=$ corn-soybean; $\mathrm{SG} / \mathrm{SB}=$ grain sorghum-soybean; $\mathrm{OCL} / \mathrm{SG} /$

$\mathrm{SB} / \mathrm{C}=$ oat + clover-grain sorghum-soybean-corn; SB/SG/OCL/C = soybean-grain sorghum-oat + clover-corn.

$\dagger$ Contrasts. Cont. $=$ continuous cropping systems; rotn. $=$ rotation cropping systems $(2$ and 4 yr $)$.

* Significant at the 0.05 probability level.

** Significant at the 0.01 probability level.

*** Significant at the $\mathbf{0 . 0 0 1}$ probability level.

1992 for the surface 0- to 7.5 -cm depth. At all three sampling times, most of the significant differences occurred between the 2-yr and 4-yr rotations, as shown by the contrasts in Table 2. In 1992, total SOC values were greater in the 4-yr than in the 2-yr systems (15.98 versus $14.78 \mathrm{Mg} \mathrm{ha}^{-1}$, respectively in the 0 to $7.5-\mathrm{cm}$ depth). Similarly, greater total SOC values were obtained in the 4-yr than in the 2-yr systems in $1998(15.74,15.17$, and $25.22 \mathrm{Mg} \mathrm{ha}^{-1}$ versus $14.24,14.39$, and $22.94 \mathrm{Mg} \mathrm{ha}^{-1}$ ) and $2002\left(15.93,15.36\right.$, and $24.62 \mathrm{Mg} \mathrm{ha}^{-1}$ versus 14.22 , 14.38 , and $22.50 \mathrm{Mg} \mathrm{ha}^{-1}$ ) at 0 - to 7.5, 7.5- to 15-, and 15to $30-\mathrm{cm}$ depths, respectively (Table 2 ). Increasing $\mathrm{N}$ fertilization also significantly increased SOC values in the 0 - to $7.5-\mathrm{cm}$ depth in 1998 when they averaged 14.58, 14.95 , and $15.24 \mathrm{Mg} \mathrm{ha}^{-1}$ and in 2002 when they averaged $14.48,14.87$, and $15.29 \mathrm{Mg} \mathrm{ha}^{-1}$ for the 0 , Low, and High fertilizer $\mathrm{N}$ levels, respectively (Table 2).

Significant crop rotation and $\mathrm{N}$ level effects on SOC values at each of these sampling dates are only part of the story. It is of greater interest to determine how SOC values change over time in these different cropping systems (i.e., some are increasing at various depths, whereas others decrease) (Table 3). Similarly, SOC values increase with increasing $\mathrm{N}$ fertilization in some cropping systems but not in others. Changes (gains or losses) in
SOC values between 1984 and 1992 and 1992 and 1998 are shown in Table 3. The changes in SOC from 1984 to 1992 shown in Table 3 are similar to those reported previously (Varvel, 1994), with significant differences due to rotation and $\mathrm{N}$ fertilizer level, but only in the surface 0 to 7.5-cm depth. Similarly, changes in SOC from 1992 to 1998 due to rotation were significant in the surface 0to 7.5-cm depth, but $\mathrm{N}$ fertilizer level was not (Table 3). A significant difference in changes in SOC from 1992 to 1998 was also found in the 15 - to 30-cm depth between 2-yr and 4-yr rotations, which was a consequence of the much greater average loss (across rotation and $\mathrm{N}$ rate) of SOC at that depth in the 2-yr $\left(-1.07 \mathrm{Mg} \mathrm{ha}^{-1}\right)$ compared with those in the 4 -yr systems $\left(-0.45 \mathrm{Mg} \mathrm{ha}^{-1}\right)$ (Table 3). These trends seemed to continue from 1998 to 2002 and from 1992 to 2002 (Table 4). Between 1998 and 2002 in the surface $0-$ to $7.5-\mathrm{cm}$ depth, only the SOC change in 2 -yr versus $4-y r$ systems was significant. However, rotation significantly affected changes in SOC in the 7.5- to $15-\mathrm{cm}$ depth, due mostly to differences between the continuous and rotation cropping systems (Table 4). When SOC changes over the longer period of time from 1992 to 2002 were calculated, rotation effects were highly significant in the 0 - to 7.5- and 7.5- to 15 -cm depths (Table 4). For example, the average loss of SOC from 1992 to 2002 
Table 3. Change in total SOC from 1984 to 1992 (four blocks) and from 1992 to 1998 (five blocks) for each rotation and N level at the 0- to 7.5-, 7.5- to 15-, and 15- to 30-cm depths at Mead, NE.

\begin{tabular}{|c|c|c|c|c|c|c|c|}
\hline \multirow[b]{3}{*}{ Rotation $\dagger$} & \multirow[b]{3}{*}{$\mathbf{N}$ level } & \multicolumn{6}{|c|}{ Depths (cm) } \\
\hline & & \multicolumn{3}{|c|}{1984 to 1992} & \multicolumn{3}{|c|}{1992 to 1998} \\
\hline & & $0-7.5$ & $7.5-15$ & 15-30 & $0-7.5$ & $7.5-15$ & 15-30 \\
\hline & & & & $-\Delta$ Total S & $\left.\mathbf{g h a}^{-1}\right)$ & & \\
\hline \multirow[t]{3}{*}{$\mathbf{C C}$} & 0 & -0.88 & -0.02 & 0.24 & 0.05 & -0.75 & -1.18 \\
\hline & Low & 0.24 & 0.29 & 0.08 & 0.27 & -0.58 & -1.55 \\
\hline & High & 0.58 & 0.69 & -0.21 & 0.42 & $-\mathbf{0 . 3 8}$ & -0.79 \\
\hline \multirow[t]{3}{*}{ CSB } & 0 & -0.05 & -0.02 & 0.14 & 0.27 & -0.24 & 0.70 \\
\hline & Low & -0.09 & -0.42 & -1.95 & 0.47 & -0.23 & -0.99 \\
\hline & High & -0.42 & -0.50 & -1.40 & 0.45 & -0.52 & -0.94 \\
\hline \multirow[t]{3}{*}{ CSG } & 0 & 0.41 & 0.09 & -0.16 & 0.52 & -0.34 & -0.36 \\
\hline & Low & 0.86 & 0.36 & -1.52 & 0.64 & -0.29 & -1.57 \\
\hline & High & 1.41 & 0.12 & -2.12 & 0.89 & -0.02 & -0.95 \\
\hline \multirow[t]{3}{*}{ C/SB } & 0 & -0.03 & -0.29 & -0.63 & 0.34 & $-\mathbf{0 . 3 6}$ & $-\mathbf{0 . 7 7}$ \\
\hline & Low & $\mathbf{0 . 3 0}$ & -0.04 & -0.59 & 0.48 & -0.91 & -1.27 \\
\hline & High & 0.14 & $-\mathbf{0 . 3 0}$ & -1.67 & 0.42 & -0.66 & -0.84 \\
\hline \multirow[t]{3}{*}{ SG/SB } & 0 & 0.24 & 0.11 & -0.07 & 0.49 & -0.80 & -1.16 \\
\hline & Low & 0.21 & -0.19 & -0.18 & 0.67 & -0.58 & -1.26 \\
\hline & High & 0.82 & 0.15 & 0.20 & 0.73 & -0.67 & $-\mathbf{1 . 1 4}$ \\
\hline \multirow[t]{3}{*}{ OCL/SG/SB/C } & 0 & 0.61 & 0.18 & $-\mathbf{0 . 0 3}$ & 0.82 & $-\mathbf{0 . 3 3}$ & -0.65 \\
\hline & Low & 0.50 & $-\mathbf{0 . 0 8}$ & $-\mathbf{1 . 8 8}$ & 0.56 & $-\mathbf{0 . 3 6}$ & $-\mathbf{0 . 2 7}$ \\
\hline & High & 1.35 & 0.28 & -0.25 & 0.95 & -0.22 & $-\mathbf{0 . 4 8}$ \\
\hline \multirow[t]{3}{*}{ SB/SG/OCL/C } & 0 & 0.87 & -0.04 & -0.69 & 0.82 & $-\mathbf{0 . 5 3}$ & $-\mathbf{0 . 4 3}$ \\
\hline & Low & 0.97 & -0.19 & -1.09 & 0.57 & -0.74 & $-\mathbf{0 . 3 9}$ \\
\hline & High & 1.38 & -0.22 & -0.84 & 0.45 & -0.24 & -0.49 \\
\hline Source of variation & df & \multicolumn{6}{|c|}{ Mean squares } \\
\hline Block & (3)(4)§ & 3.97**** & $6.57 * * *$ & 40.72*** & 1.76**** & $2.17 * * *$ & $5.37 * *$ \\
\hline Rotation & 6 & $2.90 * * *$ & 0.64 & 3.13 & $0.57 *$ & 0.49 & 1.40 \\
\hline Cont. vs. rotn. $\$$ & $\mathbf{1}$ & $3.02 * *$ & 0.27 & 0.31 & $0.86 *$ & 0.67 & 1.48 \\
\hline 2 yr vs. 4 yrt & $\mathbf{1}$ & 5.38**** & 0.08 & 1.12 & $1.44 * *$ & 0.99 & 5.81* \\
\hline Among 2 yr & 1 & 0.49 & 0.32 & 0.35 & 0.02 & 0.01 & 0.39 \\
\hline Among 4 yrit & 1 & 0.38 & 0.45 & 0.14 & 0.03 & 0.31 & 0.01 \\
\hline N level & 2 & 2.41*** & 0.04 & 5.90 & 0.22 & 0.17 & 0.85 \\
\hline Rotation $\times \mathbf{N}$ & 12 & 0.47 & 0.20 & 1.50 & 0.22 & 0.18 & 0.40 \\
\hline Error & $(60)(80) \S$ & 0.31 & 0.29 & 2.86 & 0.21 & 0.28 & 1.40 \\
\hline
\end{tabular}

$\dagger \mathrm{CC}=$ Continuous corn; $\mathbf{C S B}=$ Continuous soybean; $\mathbf{C S G}=$ Continuous grain sorghum; $\mathbf{C} / \mathrm{SB}=\mathrm{Corn}-\mathrm{soybean}$; $\mathbf{S G} / \mathrm{SB}=\mathrm{Grain}$ sorghum-soybean; OCL $/$ SG/SB/C = Oat + clover-grain sorghum-soybean-corn; SB/SG/OCL/C $=$ Soybean-grain sorghum-oat + clover-corn.

+ Contrasts. Cont. $=$ Continuous cropping systems; Rotn. $=$ Rotation cropping systems $(2$ and 4 yr $)$.

$* * *, * *, *$ Significant at the $0.001,0.01$ and 0.05 probability levels, respectively.

$\S$ Degrees of freedom for 1984 to 1992 and 1992 to 1998, respectively.

was -0.79 and $-0.73 \mathrm{Mg} \mathrm{ha}^{-1}$ in the continuous cropping systems as compared with -0.31 and $-0.45 \mathrm{Mg} \mathrm{ha}^{-1}$ in the 2- and 4-yr rotation systems at the 0 - to 7.5 -cm and 7.5- to $15-\mathrm{cm}$ depths, respectively. Similarly, the average loss of SOC from 1992 to 2002 was -0.57 and $-0.67 \mathrm{Mg} \mathrm{ha}^{-1}$ in the 2-yr rotation system, as compared with -0.05 and $-0.25 \mathrm{Mg} \mathrm{ha}^{-1}$ in the 4-yr rotation system at the 0- to 7.5-cm and 7.5- to 15-cm depths, respectively. Significant differences in SOC changes were also obtained from 1992 to 2002 between the continuous $\left(-1.85 \mathrm{Mg} \mathrm{ha}^{-1}\right)$ versus rotated systems $\left(-1.28 \mathrm{Mg} \mathrm{ha}^{-1}\right)$ in the 15 - to $30-\mathrm{cm}$ depth (Table 4).

\section{DISCUSSION}

Comparisons of point in time measurements as reported here are important for assessing changes in SOC values as affected by any management system. More importantly, it becomes necessary to examine these changes in the context of the system as they have changed over time. For example, the significant rotation effect on SOC in the 0- to 7.5-cm depth is demonstrated by similar increases for the 1984 to $1992\left(75 \mathrm{~kg} \mathrm{ha}^{-1} \mathrm{yr}^{-1}\right)$ and 1992 to $1998\left(67 \mathrm{~kg} \mathrm{ha}^{-1} \mathrm{yr}^{-1}\right)$ time periods (Table 3). Although not significant, results from the of $7.5-$ to $15-\mathrm{cm}$ depth were much different in that from 1984 to 1992 SOC levels did not change, whereas from 1992 to 1998 they decreased at the rate of $58 \mathrm{~kg} \mathrm{ha}^{-1} \mathrm{yr}^{-1}$ (Table 3). The negative trend from 1992 to 1998 continues as the results in Table 4 are examined. Decreases in SOC levels across all cropping systems from 1998 to 2002 averaged -10, -26 , and $-165 \mathrm{~kg} \mathrm{ha}^{-1} \mathrm{yr}^{-1}$ and from 1992 to 2002 averaged $-52,-57$, and $-153 \mathrm{~kg} \mathrm{ha}^{-1} \mathrm{yr}^{-1}$ for the 0 - to 7.5-, 7.5- to $15-$, and 15 - to $30-\mathrm{cm}$ depths, respectively (Table 4). These results demonstrate an interesting set of dynamics over the experiment's duration, which are best illustrated when SOC values in the surface $30-\mathrm{cm}$ for all seven of the cropping systems at the three $\mathrm{N}$ fertilizer levels are presented with time (Fig. 1). These systems are dynamic in nature, and SOC levels are still changing, even after $18 \mathrm{yr}$.

Why were SOC levels increasing in many of the cropping systems during the first $8 \mathrm{yr}$ of this study and decreasing in many of the same cropping systems over the last $10 \mathrm{yr}$ (Fig. 1)? The magnitude and consistency of these changes since 1992 caused us to review past management changes that may have prompted them. The study area was tilled twice with a tandem disk just before planting for all crops. From 1984 to 1992, the tandem disk used was $3.6 \mathrm{~m}$ wide with 38.1-cm diameter disks, but from 1992 to 2002, a 5.5-m wide tandem disk 
Table 4. Change in total SOC from 1998 to 2002 and from 1992 to 2002 for each rotation and N level at the 0- to 7.5-, 7.5- to 15-, and 15- to 30-cm depths at Mead, NE.

\begin{tabular}{|c|c|c|c|c|c|c|c|}
\hline \multirow[b]{3}{*}{ Rotation $\dagger$} & \multirow[b]{3}{*}{$\mathbf{N}$ level } & \multicolumn{6}{|c|}{ Depths (cm) } \\
\hline & & \multicolumn{3}{|c|}{1998 to 2002} & \multicolumn{3}{|c|}{1992 to 2002} \\
\hline & & $0-7.5$ & $7.5-15$ & 15-30 & $0-7.5$ & $7.5-15$ & 15-30 \\
\hline & & & & $-\Delta$ Tota & Mg ha' $\left.{ }^{-1}\right)$ & & \\
\hline \multirow{3}{*}{$\mathrm{CC}$} & 0 & -0.43 & -0.54 & -1.56 & -1.62 & -1.29 & -2.73 \\
\hline & Low & $-\mathbf{0 . 4 8}$ & $-\mathbf{0 . 5 2}$ & $-\mathbf{0 . 5 0}$ & $-\mathbf{1 . 1 5}$ & $-\mathbf{1 . 1 1}$ & -2.05 \\
\hline & High & $-\mathbf{0 . 3 8}$ & -0.52 & -0.69 & -0.77 & -0.89 & -1.48 \\
\hline \multirow[t]{3}{*}{ CSB } & 0 & -0.19 & -0.72 & -0.97 & -0.88 & -0.96 & -1.67 \\
\hline & Low & -0.29 & -0.40 & -0.59 & -0.76 & -0.62 & -1.59 \\
\hline & High & 0.25 & $\mathbf{0 . 1 7}$ & -0.55 & $-\mathbf{0 . 4 1}$ & $-\mathbf{0 . 3 5}$ & -1.49 \\
\hline \multirow[t]{3}{*}{ CSG } & 0 & -0.17 & -0.15 & -0.97 & $-\mathbf{0 . 6 0}$ & -0.48 & $-\mathbf{1 . 3 2}$ \\
\hline & Low & 0.02 & -0.26 & $-\mathbf{1 . 2 9}$ & $-\mathbf{0 . 3 5}$ & -0.54 & -2.86 \\
\hline & High & -0.26 & $-\mathbf{0 . 3 2}$ & $-\mathbf{0 . 5 3}$ & -0.61 & $-\mathbf{0 . 3 4}$ & $-\mathbf{1 . 4 9}$ \\
\hline \multirow[t]{3}{*}{ C/SB } & 0 & 0.00 & -0.16 & $-\mathbf{0 . 5 0}$ & $-\mathbf{0 . 5 8}$ & -0.52 & -1.27 \\
\hline & Low & -0.07 & 0.18 & -0.28 & -0.80 & -0.73 & -1.55 \\
\hline & High & 0.15 & $\mathbf{0 . 0 5}$ & -0.04 & $-\mathbf{0 . 2 7}$ & -0.61 & $-\mathbf{0 . 8 8}$ \\
\hline \multirow[t]{3}{*}{ SG/SB } & 0 & $-\mathbf{0 . 0 8}$ & -0.05 & -0.67 & $-\mathbf{0 . 8 2}$ & $-\mathbf{0 . 8 5}$ & -1.84 \\
\hline & Low & $-\mathbf{0 . 0 5}$ & -0.14 & -0.44 & $-\mathbf{0 . 3 6}$ & -0.72 & $-\mathbf{1 . 7 0}$ \\
\hline & High & -0.04 & 0.07 & -0.66 & $-\mathbf{0 . 5 7}$ & -0.60 & $-\mathbf{1 . 8 0}$ \\
\hline \multirow[t]{3}{*}{ OCL/SG/SB/C } & 0 & 0.15 & -0.01 & $-\mathbf{0 . 5 7}$ & $-\mathbf{0 . 1 6}$ & $-\mathbf{0 . 3 4}$ & $-\mathbf{1 . 2 3}$ \\
\hline & Low & 0.04 & 0.22 & -0.72 & $-\mathbf{0 . 1 4}$ & $-\mathbf{0 . 1 4}$ & -0.99 \\
\hline & High & 0.10 & -0.01 & -0.96 & -0.04 & $-\mathbf{0 . 2 3}$ & -1.44 \\
\hline \multirow{3}{*}{ SB/SG/OCL/C } & 0 & 0.08 & 0.29 & $-\mathbf{0 . 1 7}$ & 0.05 & -0.24 & $-\mathbf{0 . 6 0}$ \\
\hline & Low & 0.30 & 0.30 & -0.89 & -0.12 & -0.45 & -1.28 \\
\hline & High & 0.51 & 0.33 & $-\mathbf{0 . 2 9}$ & $\mathbf{0 . 1 2}$ & 0.09 & $-\mathbf{0 . 7 8}$ \\
\hline Source of variation & df & \multicolumn{6}{|c|}{ Mean squares } \\
\hline Block & 4 & $0.49 *$ & 0.35 & 1.06 & $2.88 * * *$ & $3.60 * * *$ & $4.18 *$ \\
\hline Rotation & 6 & 0.74 & $1.14 * * *$ & 0.86 & 2.31*** & $1.42 * * *$ & 2.75 \\
\hline Cont. vs. rotn. $\$$ & 1 & 2.37 & 5.18*** & 2.82 & $6.09 * * *$ & 2.11* & 8.40* \\
\hline 2 yr vs. 4 yr & 1 & $0.66 *$ & 0.58 & 0.43 & $4.05 * * *$ & 3.08** & 3.08 \\
\hline Among 2 yr & 1 & 0.05 & 0.03 & 0.75 & 0.01 & 0.08 & 2.23 \\
\hline Among 4 yrt & $\mathbf{1}$ & 0.30 & 0.43 & 0.66 & 0.13 & 0.01 & 0.81 \\
\hline N level & 2 & 0.21 & 0.23 & 0.52 & 0.76 & 0.60 & 1.27 \\
\hline Rotation $\times \mathbf{N}$ & 12 & 0.11 & 0.19 & 0.55 & 0.21 & 0.11 & 0.96 \\
\hline Error & 80 & 0.17 & 0.26 & 0.86 & 0.24 & 0.32 & 1.39 \\
\hline
\end{tabular}

$\dagger \mathrm{CC}=$ Continuous corn; $\mathbf{C S B}=$ Continuous soybean; $\mathbf{C S G}=$ Continuous grain sorghum; C/SB $=$ Corn-soybean; $\mathbf{S G} / \mathrm{SB}=\mathbf{G r a i n}$ sorghum-soybean; OCL $/$ SG/SB/C = Oat + clover-grain sorghum-soybean-corn; SB/SG/OCL/C $=$ Soybean-grain sorghum-oat + clover-corn.

$\doteqdot$ Contrasts. Cont. $=$ Continuous cropping systems; Rotn. $=$ Rotation cropping systems $(2$ and 4 yr $)$.

$* * *, * *$ * Significant at the $0.001,0.01$ and 0.05 probability levels, respectively.

with 50.8-cm diameter disks was used. This practice resulted in a much greater depth of tillage since 1992, approximately $15-20 \mathrm{~cm}$ versus $10-15 \mathrm{~cm}$ for the first $8 \mathrm{yr}$, which could explain the greater loss in SOC from 1992 to 2002 in most of the cropping systems (Table 4 and Fig. 1). Tillage to a greater depth for the last $10 \mathrm{yr}$ seems to have caused SOC values to significantly decrease in the surface 0 - to $7.5-$ and $7.5-$ to $15-\mathrm{cm}$ depths (Table 4). The overall effects of the increased depth of tillage are illustrated in Fig. 1, which shows SOC values in the surface $30 \mathrm{~cm}$ for all cropping systems for the duration of the study.

We observed that the decreases in SOC values for the total depth of sampling $(0-30 \mathrm{~cm})$ from 1992 to 2002 were much greater in the monoculture and 2-yr cropping systems (averaging $-3.13 \mathrm{Mg} \mathrm{ha}^{-1}$ ) versus those in the 4-yr cropping systems (averaging $-0.73 \mathrm{Mg} \mathrm{ha}^{-1}$ ) (Table 4 and Fig. 1). This observation is similar to results recently reported by Hooker et al. (2005), who suggested that the annual return of aboveground biomass may not increase SOC storage as greatly as the belowground biomass. In our study, the 4-yr cropping systems with an oat+clover crop once every 4 yr may be contributing a much greater amount of belowground biomass than any of the monocultures or 2-yr cropping systems. Maintenance of SOC levels over the $18 \mathrm{yr}$ of this study in our 4-yr cropping systems with clover (Fig. 1) also agree with results recently reported by Russell et al. (2005) in Iowa, where they found that cropping systems including alfalfa for 1 to $2 \mathrm{yr}$ in a 4-yr rotation are a viable management option for increasing SOC stocks. Together, these results point to the importance of diversification of crops and longer-term rotations in maintaining SOC levels.

\section{CONCLUSIONS}

Change or lack of change in SOC values as measured in this long-term experiment demonstrates two very important principles. First, in so-called conventionally tilled systems such as this one, an increase in tillage depth resulted in increased SOC losses and second, as was found earlier (Varvel, 1994), cropping systems, especially 4-yr systems with clover may significantly increase or at a minimum, reduce losses of SOC.

Both of these results illustrate that more than one point-in-time measurement from long-term experiments is necessary to monitor SOC changes (Fig. 1) when several management variables are being used. In addition, they also indicate that apparent small changes in cultural practices, such as in depth of tillage in this 

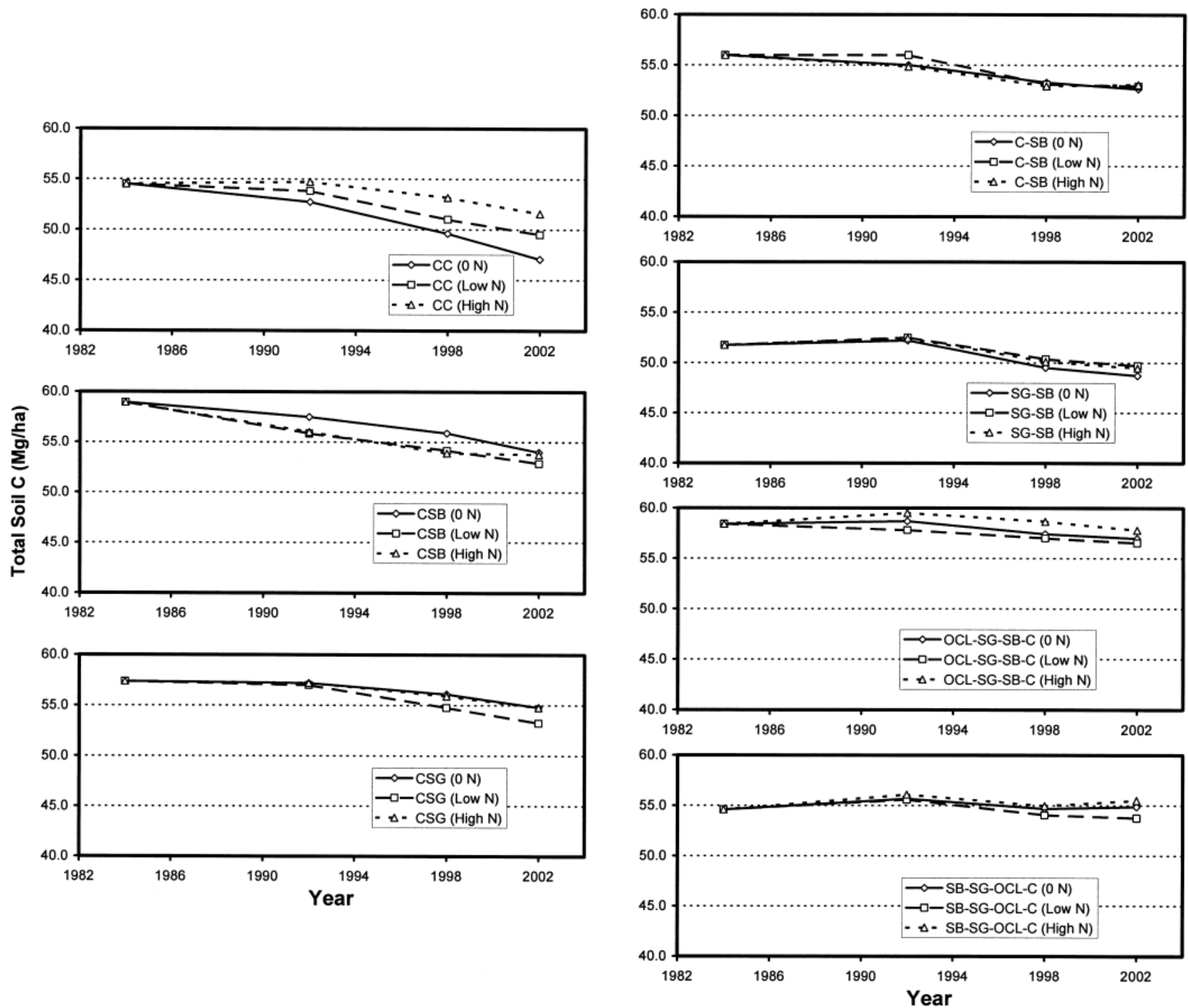

Fig. 1. Total SOC in the surface 30-cm depth at Mead, $\mathrm{NE}$ as affected by cropping system and $\mathrm{N}$ fertilizer level at several points in time during the first 18 yr of the study. Monoculture systems $(C C=$ continuous corn, $C S B=$ continuous soybean, and CSG $=$ continuous grain sorghum $)$ are plotted on the left. On the right side are plotted 2-yr C/SB $=$ corn-soybean, SG/SB $=$ grain sorghum-soybean above the 4-yr cropping systems, OCL/SG/SB/C = oat + clover-grain sorghum-soybean-corn, and SB/SG/OCL/C $=$ soybean-grain sorghum-oat + clover-corn.

experiment, can significantly change SOC dynamics in the study. This result becomes especially significant if $\mathrm{C}$ credits are to be considered for agricultural production systems.

\section{REFERENCES}

Allmaras, R.R., D.R. Linden, and C.E. Clapp. 2004. Corn-residue transformations into root and soil carbon as related to nitrogen, tillage, and stover management. Soil Sci. Soc. Am. J. 68:1366-1375.

Booker, B.A., T.F. Morris, R. Peters, and Z.G. Cardon. 2005. Longterm effects of tillage and corn stalk return on soil carbon dynamics. Soil Sci. Soc. Am. J. 69:188-196.

Franzluebbers, A.J., and M.A. Arshad. 1996. Soil organic matter pools during early adoption of conservation tillage in northwestern Canada. Soil Sci. Soc. Am. J. 60:1422-1427.

Hooker, B.A., T.F. Morris, R. Peters, and Z.G. Cardon. 2005. Longterm effects of tillage and corn stalk removal on soil carbon dynamics. Soil Sci. Soc. Am. J. 69:188-196.
Jarecki, M.K., and R. Lal. 2003. Crop management for soil carbon sequestration. Crit. Rev. In Plant Sci. CRC Press LLC, Boca Raton, FL. 22:471-502.

Lal, R., J.M. Kimble, R.F. Follett, and C.V. Cole. 1998. The potential of U.S. cropland to sequester carbon and mitigate the greenhouse effect. Sleeping Bear Press, Chelsea, MI.

Peterson, T.A., and G.E. Varvel. 1989a. Crop yield as affected by crop rotation and $\mathrm{N}$ rate. I. Soybean. Agron. J. 81:727-731.

Peterson, T.A., and G.E. Varvel. 1989b. Crop yield as affected by crop rotation and $\mathrm{N}$ rate. II. Sorghum. Agron. J. 81:731-734.

Peterson, T.A., and G.E. Varvel. 1989c. Crop yield as affected by crop rotation and N rate. III. Corn. Agron. J. 81:735-738.

Russell, A.E., D.A. Laird, T.B. Parkin, and A.P. Mallarino. 2005. Impact of nitrogen fertilization and cropping system on carbon sequestration in midwestern mollisols. Soil Sci. Soc. Am. J. 69:413-422.

SAS Institute. 1992. SAS/STAT User's Guide. 4th ed. SAS Institute, Inc. Cary, NC.

Schepers, J.S., D.D. Francis, and M.T. Thompson. 1989. Simultaneous determination of total $\mathrm{C}$, total $\mathrm{N}$, and ${ }^{15} \mathrm{~N}$ on soil and plant material. Commun. Soil Sci. Plant Anal. 20:949-959. 
Steel, R.G., and J.H. Torrie. 1980. Principles and procedures of statistics. A biometrical approach. 2nd ed. McGraw-Hill Book Co., New York. Varvel, G.E. 1994. Rotation and nitrogen fertilization effects on changes in soil carbon and nitrogen. Soil Sci. Soc. Am. J. 86: $319-325$.

West, T.O., and W.M. Post. 2002. Soil organic carbon sequestration rates by tillage and crop rotation: A global data analysis. Soil Sci. Soc. Am. J. 66:1930-1946.

Wilts, A.R., D.C. Reicosky, R.R. Allmaras, and C.E. Clapp. 2004. Long-term corn residue effects: Harvest alternatives, soil carbon turnover, and root-derived carbon. Soil Sci. Soc. Am. J. 68: $1342-1351$. 


\title{
Soil Organic Carbon Changes in Diversified Rotations of the Western Corn Belt
}

\author{
G.E. Varvel
}

Soil Sci. Soc. Am. J. 70:426-433

Table 1 (p. 428) and Table 3(p. 430) have incorrect data. In Table 1, the Total SOC in the last column for the 15- to 30-cm depth in 1992 is incorrect. In Table 3, $\Delta$ Total SOC in the 0- to 7.5-cm depth from 1992 to 1998 is incorrect. The correct tables are below.

Table 1. Total SOC in 1984 for each rotation and 1992 for each rotation and $\mathrm{N}$ level at the 0 to $7.5,7.5$ to 15 , and 15 to $30-\mathrm{cm}$ depths in the first four blocks at Mead, Nebraska.

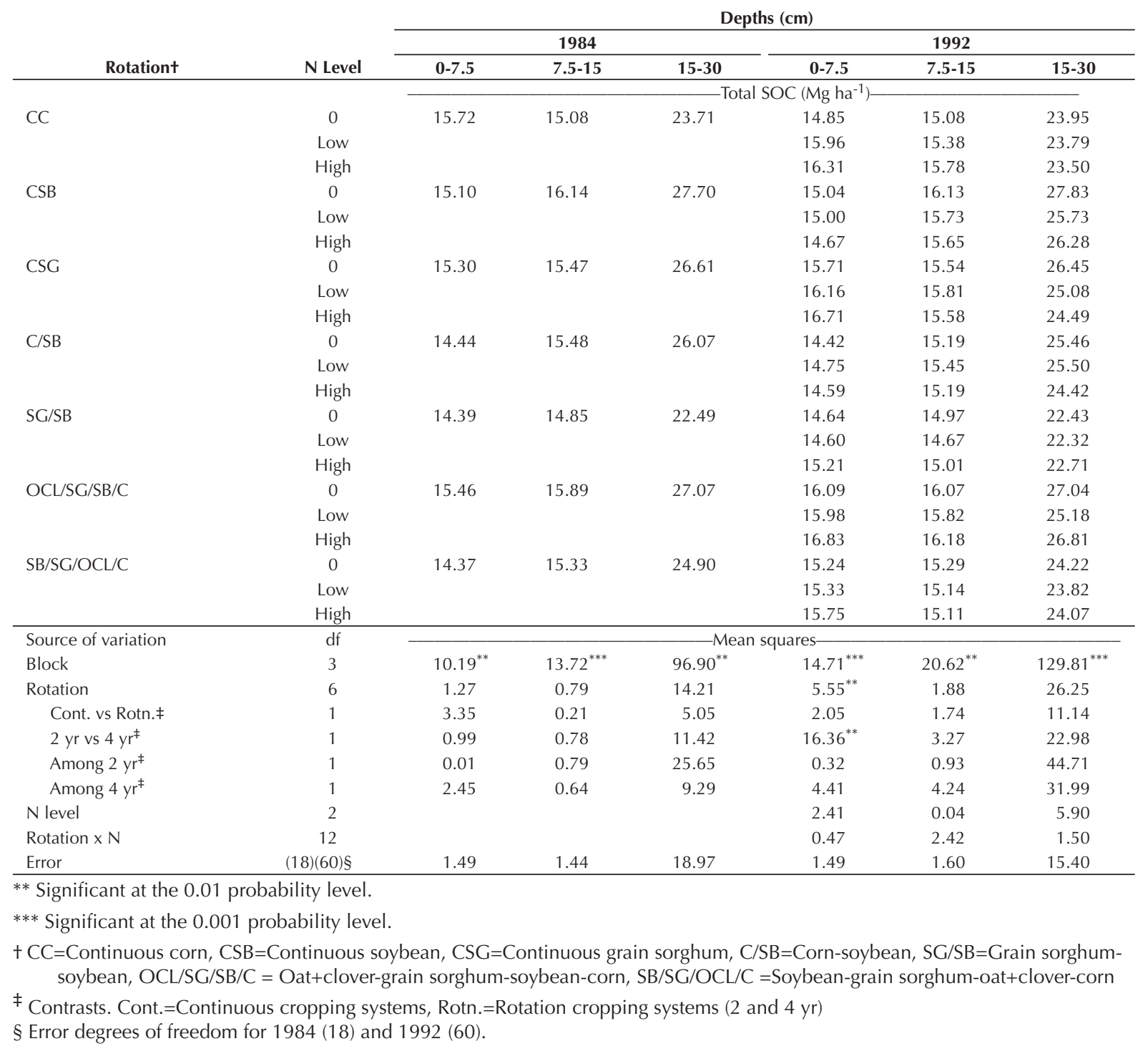

Soil Sci. Soc. Am. J. 72:567-568

doi:10.2136/sssaj2005.0100er

CSoil Science Society of America

677 S. Segoe Rd. Madison WI 53711 USA

All rights reserved. No part of this periodical may be reproduced or transmitted in any form or by any means, electronic or mechanical, including photocopying, recording, or any information storage and retrieval system, without permission in writing from the publisher. Permission for printing and for reprinting the material contained herein has been obtained by the publisher 
Table 3. Change in total SOC from 1984 to 1992 (4 blocks) and from 1992 to 1998 (5 blocks) for each rotation and $\mathrm{N}$ level at the 0 to $7.5,7.5$ to 15 , and 15 to $30-\mathrm{cm}$ depths at Mead, NE.

\begin{tabular}{|c|c|c|c|c|c|c|c|}
\hline \multirow{3}{*}{ Rotationt } & \multirow[b]{3}{*}{ N Level } & \multicolumn{6}{|c|}{ Depths $(\mathrm{cm})$} \\
\hline & & \multicolumn{3}{|c|}{1984 to 1992} & \multicolumn{3}{|c|}{1992 to 1998} \\
\hline & & $0-7.5$ & 7.5-15 & $15-30$ & $0-7.5$ & $7.5-15$ & $15-30$ \\
\hline & & & & $\Delta$ Total S & $\left.h a^{-1}\right)$ & & \\
\hline \multirow[t]{3}{*}{$\mathrm{CC}$} & 0 & -0.88 & -0.02 & 0.24 & -1.19 & -0.75 & -1.18 \\
\hline & Low & 0.24 & 0.29 & 0.08 & -0.67 & -0.58 & -1.55 \\
\hline & High & 0.58 & 0.69 & -0.21 & -0.39 & -0.38 & -0.79 \\
\hline \multirow[t]{3}{*}{ CSB } & 0 & -0.05 & -0.02 & 0.14 & -0.68 & -0.24 & -0.70 \\
\hline & Low & -0.09 & -0.42 & -1.95 & -0.47 & -0.23 & -0.99 \\
\hline & High & -0.42 & -0.50 & -1.40 & -0.66 & -0.52 & -0.94 \\
\hline \multirow[t]{3}{*}{ CSG } & 0 & 0.41 & 0.09 & -0.16 & -0.42 & -0.34 & -0.36 \\
\hline & Low & 0.86 & 0.36 & -1.52 & -0.37 & -0.29 & -1.57 \\
\hline & High & 1.41 & 0.12 & -2.12 & -0.34 & -0.02 & -0.95 \\
\hline \multirow[t]{3}{*}{$\mathrm{C} / \mathrm{SB}$} & 0 & -0.03 & -0.29 & -0.63 & -0.57 & -0.36 & -0.77 \\
\hline & Low & 0.30 & -0.04 & -0.59 & -0.73 & -0.91 & -1.27 \\
\hline & High & 0.14 & -0.30 & -1.67 & -0.42 & -0.66 & -0.84 \\
\hline \multirow[t]{3}{*}{$\mathrm{SG} / \mathrm{SB}$} & 0 & 0.24 & 0.11 & -0.07 & -0.74 & -0.80 & -1.16 \\
\hline & Low & 0.21 & -0.19 & -0.18 & -0.30 & -0.58 & -1.26 \\
\hline & High & 0.82 & 0.15 & 0.20 & -0.53 & -0.67 & -1.14 \\
\hline \multirow[t]{3}{*}{$\mathrm{OCL} / \mathrm{SG} / \mathrm{SB} / \mathrm{C}$} & 0 & 0.61 & 0.18 & -0.03 & -0.30 & -0.33 & -0.65 \\
\hline & Low & 0.50 & -0.08 & -1.88 & -0.17 & -0.36 & -0.27 \\
\hline & High & 1.35 & 0.28 & -0.25 & -0.14 & -0.22 & -0.48 \\
\hline \multirow[t]{3}{*}{ SB/SG/OCL/C } & 0 & 0.87 & -0.04 & -0.69 & -0.02 & -0.53 & -0.43 \\
\hline & Low & 0.97 & -0.19 & -1.09 & -0.41 & -0.74 & -0.39 \\
\hline & High & 1.38 & -0.22 & -0.84 & -0.38 & -0.24 & -0.49 \\
\hline \multicolumn{2}{|l|}{ Source of variation } & \multicolumn{6}{|c|}{ Mean squares } \\
\hline Block & $(3)(4)^{\S}$ & $3.97^{* * *}$ & $6.57^{* * *}$ & $40.72^{* * *}$ & $1.76^{* * *}$ & $2.17^{* * *}$ & $5.37^{* *}$ \\
\hline Rotation & 6 & $2.90^{* * *}$ & 0.64 & 3.13 & $0.57^{*}$ & 0.49 & 1.40 \\
\hline Cont. vs Rotn.‡ & 1 & $3.02^{* *}$ & 0.27 & 0.31 & $0.86^{*}$ & 0.67 & 1.48 \\
\hline 2 yr vs 4 yrł & 1 & $5.38^{* * *}$ & 0.08 & 1.12 & $1.44^{* *}$ & 0.99 & $5.81^{*}$ \\
\hline Among 2 yr‡ & 1 & 0.49 & 0.32 & 0.35 & 0.02 & 0.01 & 0.39 \\
\hline Among 4 yr & 1 & 0.38 & 0.45 & 0.14 & 0.03 & 0.31 & 0.01 \\
\hline $\mathrm{N}$ level & 2 & $2.41^{* * *}$ & 0.04 & 5.90 & 0.22 & 0.17 & 0.85 \\
\hline Rotation $\times \mathrm{N}$ & 12 & 0.47 & 0.20 & 1.50 & 0.22 & 0.18 & 0.40 \\
\hline Error & $(60)(80)^{\S}$ & 0.31 & 0.29 & 2.86 & 0.21 & 0.28 & 1.40 \\
\hline
\end{tabular}

**Significant at the 0.01 probability levels.

*** Significant at the 0.001 probability levels.

$+\mathrm{CC}=$ Continuous corn, $\mathrm{CSB}=$ Continuous soybean, $\mathrm{CSG}=$ Continuous grain sorghum, $\mathrm{C} / \mathrm{SB}=\mathrm{Corn}$-soybean, SG/SB=Grain sorghum-soybean,

$\mathrm{OCL} / \mathrm{SG} / \mathrm{SB} / \mathrm{C}=$ Oat+clover-grain sorghum-soybean-corn, SB/SG/OCL/C =Soybean-grain sorghum-oat+clover-corn

₹ Contrasts. Cont.=Continuous cropping systems, Rotn.=Rotation cropping systems ( 2 and 4 yr)

$\S$ Degrees of freedom for 1984 to 1992 and 1992 to 1998, respectively. 